\title{
Performance of a mid-sized harvester-forwarder system in integrated harvesting of sawmill, pulpwood and firewood
}

\author{
A.I. Apăfăian, A.R. Proto, S.A. Borz
}

Apăfăian A.I., Proto A.R., Borz S.A., 2017. Performance of a mid-sized harvester-forwarder system in integrated harvesting of sawmill, pulpwood and firewood. Ann. For. Res. 60(2): 227-241.

Abstract. Fully mechanized timber harvesting systems are generally characterized by a high operational performance being widespread and used across many regions. Such systems are adaptable to different levels of operational integration, enabling also the recovery of energy wood, but given integration configurations affect their performance. A production study was carried out in a Norway spruce clear-cut aiming to investigate the performance of a mid-sized harvester-forwarder system in general, and the effect that fuelwood recovery from tree tops may have on its performance. Data was collected in the field during 11 days of observation using state-ofart equipment and software. Harvester's operations were monitored using a digital camera. Data refined from 27.5 filmed hours that accounted for 1045 felled and fully processed trees was used to model and compute its performance indicators. In addition, fuel consumption data was sampled in the field. The results indicated that a delay-free cycle time consumption was affected by variables characterizing the tree size. The net production rate was estimated to about $26.5 \mathrm{~m}^{3} \cdot \mathrm{h}^{-1}$, being substantially affected by supplementary tree-top processing. Forwarding operations were monitored using a handheld computer and a Global Positioning System unit. The delay-free cycle time consumption was affected by forwarding distance and the amount of loaded wood, resulting in a net production rate of about 19.2 $\mathrm{m}^{3} \cdot \mathrm{h}^{-1}$. Under these circumstances, the forwarding performance matched the harvester's outputs for an extraction distance of about $100 \mathrm{~m}$, indicating that the supplementary processing of the tree-tops had no effect on the system's productive performance in the studied conditions. Most like$1 y$, it affected the harvester's fuel consumption given its proportion of $9 \%$ in the delay-free harvester's cycle time. The results also indicated a mean fuel consumption of about $1.71 \cdot \mathrm{m}^{-3}$ for the studied harvesting system. Keywords cut-to-length, fully mechanized, fuelwood recovery, integration, harvester-forwarder, operational performance

Authors. Andrei Ioan Apăfăian, Stelian Alexandru Borz (stelian.borz@unitbv. ro) - Department of Forest Engineering, Forest Management Planning and Terrestrial Measurements, Faculty of Silviculture and Forest Engineering, Transilvania University of Braşov, Şirul Beethoven No. 1, 500123, Braşov, Romania; 
Andrea Rosario Proto - Department of Agriculture, Mediterranean University of Reggio Calabria, Feo di Vito 89122, Reggio Calabria, Italy.

Manuscript received August 28, 2017; revised November 11, 2017; accepted November 29, 2017; online first December , 2017.

\section{Introduction}

Forest operations are seen nowadays as a key component of a sustainable wood procurement supply chain, aiming to enable a steady, yet quantitative and qualitative sufficient wood delivery, at minimal input of resources such as time, energy and effort, maximum productivity and minimum to no environmental impact (Heinimann 2012), often involving several transformations of the timber in terms of shape and location (Oprea 2008). The need to reduce the pressure on forest ecosystems, as well as to enhance the harvesting performance, has led in time to the development of a number of harvesting systems (Ionaşcu et al. 2006) with the fully mechanized ones usually assembling high performance machines (Oprea 2008). In Romania, timber harvesting rely almost exclusively on harvesting systems that use chainsaws and skidders or farm tractors (Oprea 2008). However, in small scale forest operations it is quite usual to use solely draft horses that are characterized by low productive performances (Borz \& Ciobanu 2013). Nevertheless, coupling draft horses with skidders may result in feasible extraction options (Magagnotti \& Spinelli 2011). Skidding performance, on the other hand, is rather low due to reasons such as reduced accessibility conditions (Borz et al. 2015) and a poor management of workplace time often resulting in great delays (Borz et al. 2013). Then, the motor-manual tree felling and processing may cause serious injuries, even fatalities (Borz et al. 2014) while the workers are exposed to noise (Tunay \& Melemez 2008), vibrations (Rottensteiner et al. 2012) and they are required to take uncomfortable postures during their work (Corella et al. 2015). On the other hand, the fully mechanized harvester-forwarder systems proved to be high- ly productive and less physically demanding (Inoue \& Kobayashi 1996) but they are very sensitive to the operational layout. While their use is safer (Bell 2001), under given circumstances, operations with such machines can be mentally demanding (Inoue 1996) and require substantial cognitive abilities (Ovaskainen \& Heikkila 2007). Being equipped with felling and processing heads, harvesters are able to fully process the trees into logs.

Time consumption and productivity of harvesting systems are dependent on factors characterizing the stand conditions, operator's skills, working techniques and the characteristics of forest machinery (Nurminen et al. 2006). For harvesters, among these factors are the tree size, harvesting intensity, tree species, terrain configuration and the approach used to process the trees. Studies carried out in Nordic countries and in the North America pointed out that the cutting productivity of single-grip harvesters increases with increasing stem size (Nurminen et al. 2006) but the relationship between the two is not linear. At a certain point however, after reaching an optimum stem size the productivity starts to decrease (Nurminen et al. 2006, Visser \& Spinelli 2011). In steep terrains the slope and the soil bearing capacity are considered to be additional factors which affect the locomotion performance (Stampfer \& Steinmuller 2001) therefore the productivity of harvesters. However, the number of factors used to explain the variation of productivity differs from one study to another in relation to the strategy used to collect the data and the data availability. For instance, in a large-scale study, Gerasimov et al. (2012) used the data extracted from the harvesters' monitoring systems to model the productivity as a function of stem size and tree species.

Based on the synthesis of Nurminen et al. 
(2006), in the case of forwarders, the stand type, extraction distance, terrain configuration, timber density on the strip road and the load per turn (which is also related to the forwarder size) are considered to be relevant factors affecting the productivity as reported in previous studies. Such factors were considered relevant also by other studies (e.g. Stankic et al. 2012) who derived forwarding productivity models from over 1440 work cycles. When operating in steep terrains, however, the slope is also considered as a relevant factor affecting the forwarding productivity (Ghaffaryian et al. 2007).

At the same time, the full recovery of the wood by integration of harvesting systems and methods enables the extraction of other products such as the energy wood. Nowadays, there are many integrated recovery options used in practice. A common option used in first thinning operations is that of integrating the harvesting of energy wood and pulpwood (Laitila \& Väätäinen 2013) which requires further comminution of the recovered energy wood. Obviously, such an option limits the tree processing in the forest with benefits for harvesters' productivity but its use is reasonable in those conditions where the comminution technology is available and wood chips can be produced. This is not the case, however, of the underdeveloped communities where such technology as well as the terminals designed for combustion of woodchips are scarce. Here predominates instead the use of regular firewood which is produced in most cases using manual labor (Oprea 2008). A solution able to limit or exclude the manual labor in producing regular firewood is that to use mechanical means to produce such assortments on site. While harvesters are regularly used to produce saw logs and pulpwood, they have the capability to process also the wood from the tree tops into firewood assortments. Of course, there is the question on if and how the integration of firewood recovery into the regular way of work of the harvester-forwarder system may affect its performance because of supplementary processing of the tree tops. To this end, the overall performance of harvesting systems may be evaluated in different ways. Usually, objective indicators such as the efficiency and productivity are used to characterize their productive performance (Björheden et al. 1995). In particular, modelling studies (Acuna et al. 2012) are useful in the attempt to understand the operational behavior of a given harvesting system or machine being studied under new conditions (Visser \& Spinelli 2011) including here the regional specificity of harvesting systems and operations (Hiesl \& Benjamin 2013).

The aim of this study was to evaluate the performance of a cut-to-length midsized harvester-forwarder harvesting system in Norway spruce clear-cuts when supplementary processing the tree-tops, by producing relevant statistics of time consumption, developing predictive models to understand the system's behavior relative to the operational variables, measuring the fuel consumption and estimating the system's productivity.

\section{Materials and methods}

\section{Study site}

This study was carried out in 2014 in an evenaged, 45-year old Norway spruce (Picea abies) forest stand located in the eastern part of Romania (Figure 1) on the Moldavian Plateau $\left(47^{\circ} 16^{\prime} 17^{\prime \prime} \mathrm{N}, 26^{\circ} 35^{\prime} 03^{\prime \prime} \mathrm{E}\right)$ near the Cristeşti village (Iaşi County). The forest stand from the studied location was severely affected by drought. In order to remove the dried-out trees, a clear cut was authorized for an area of 30.7 hectares. A description of site and vegetation conditions as they were prior the harvesting operations is given in Table 1.

\section{Equipment description and operational layout}

Harvesting operations were carried out in the 
Table 1 Description of site and pre-harvest data

\begin{tabular}{lll}
\hline Element & Measurement unit & Value \\
\hline Site characteristics & & \\
Altitude above the sea level (mean) & $\mathrm{m}$ & 373 \\
Area & ha & 30.7 \\
Terrain gradient (mean) & $\%$ & 10 \\
Soil type & - & luvosoil \\
\hline Stand characteristics & - & \\
Composition & trees $\cdot$ ha $^{-1}$ & 620 \\
Density & $\mathrm{m}$ & 18.5 \\
Average tree height (TH) & $\mathrm{cm}$ & 23 \\
Average diameter at the breast height (DBH) & 60 \\
Pruning condition (mean) & $\%$ of TH & 0.364 \\
Average tree volume (TV) & $\mathrm{m}^{3} \cdot$ tree $^{-1}$ & \\
\hline Other characteristics & & clear cut \\
Silvicultural system & - & cut-to-length* \\
Harvesting method & - & harvester-forwarder \\
Harvesting system & - &
\end{tabular}

summer-autumn of 2014. Tree conversion in saw-logs $(3 \mathrm{~m})$ and pulpwood $(4 \mathrm{~m})$ was done by a mid-class 16.1 ton Valmet 911.4 harvester equipped with a $170 \mathrm{~kW}$ engine. The harvester was equipped with a 360.2 series felling and processing head. Forwarding operations were carried out by a mid-size 15.6 ton Komatsu 840.4 forwarder equipped with a 130 $\mathrm{kW}$ engine. The operations were carried out under sunny dry weather conditions. Prior to the effective data collection, all the tasks that were specific to the studied harvesting system were monitored during an operational day, a fact that allowed to design on-the-spot the data collection layout for the forwarder. However, the study layout for the harvester was designed at the office based on the video data collected in the field. The observed operational layout is shown in Figure 1. The harvester's work pattern included advancements on forest strips that had a width of approximately double the boom reach, combined with tree felling and processing. The felled trees were processed on the same side relative to the direction of advancement, resulting in a harvesting slash placed on a continuous pile. A special requirement of the forest administrator was that of supplementary processing the tree tops, in or230 der to get delimbed smaller pieces in the harvesting slash, as a possibility to recover some of the slash-wood for energetic purposes. The work tasks of the analyzed harvesting system were broken into time and work elements that are described in Table 2.

\section{Data collection}

The methods used to collect the field data were designed in order to gather as much as possible information in the field. A Traveler DC-12 digital video camera equipped with a 12-megapixel objective and a storage capacity of 32 megabytes was placed in the harvester cab using a frontal windscreen mount. The camera was placed in a position that enabled it to fully collect the outside operations with minimal vision obstructions for the harvester's operator. The device was programmed to record video files having 1 hour in length each and the harvester's operator was asked to restart the camera each time it stopped as well as to replace the used batteries. At the end of a given work day, all the resulted video files were transferred into a personal computer (PC). While this approach was very helpful in collecting detailed time consumption data by sampling in a very accu- 
Table 2 Main characteristics of the vehicles

\begin{tabular}{|c|c|c|}
\hline $\begin{array}{l}\text { Work (time) } \\
\text { element }\end{array}$ & Abbreviation & Definition \\
\hline \multicolumn{3}{|l|}{ Harvester } \\
\hline $\begin{array}{l}\text { Moving to } \\
\text { (between) tree } \\
\text { groups to be } \\
\text { harvested }\end{array}$ & $\mathrm{mtg}\left(\mathrm{t}_{\mathrm{mtg}}\right)$ & $\begin{array}{l}\text { The effective movement of the machine, overlapping sometimes the } \\
\text { boom's movements. Begins when the wheels start to turn and ends when } \\
\text { the machine halts in range of tree to be harvested }\end{array}$ \\
\hline Swing to fell & $\mathrm{sf}\left(\mathrm{t}_{\mathrm{sf}}\right)$ & $\begin{array}{l}\text { The effective movement of the boom, overlapped sometimes with the } \\
\text { machine movement. Begins when the boom moves towards a tree and } \\
\text { ends when the processor head grabbing arms start to open }\end{array}$ \\
\hline Tree securing & ts $\left(t_{t s}\right)$ & $\begin{array}{l}\text { The effective tree grabbing, sometimes overlapped by other work } \\
\text { elements. Begins when the grapple-arm grabs a standing tree and ends } \\
\text { right before the first saw movement }\end{array}$ \\
\hline Felling cut & $\mathrm{fc}\left(\mathrm{t}_{\mathrm{fc}}\right)$ & $\begin{array}{l}\text { The effective cut action performed by the saw, including repetitive } \\
\text { sawing actions, sometimes absent. Begins when the sawdust starts to be } \\
\text { expelled and ends when the tree detaches from the stump }\end{array}$ \\
\hline $\begin{array}{l}\text { Swing to } \\
\text { process }\end{array}$ & $\mathrm{sp}\left(\mathrm{t}_{\mathrm{sp}}\right)$ & $\begin{array}{l}\text { The effective tree movement by the boom to the processing place. } \\
\text { Begins when the tree is detached from the stump and ends when the } \\
\text { feeding rollers start to spin }\end{array}$ \\
\hline Tree delimbing & $\operatorname{td}\left(t_{t d}\right)$ & $\begin{array}{l}\text { The effective movement of the rollers over the tree to be processed, } \\
\text { sometimes repeated for the same tree portion and sometimes not } \\
\text { effectively producing delimbing but rather advancement on the tree in } \\
\text { order to make a given cut. Begins when the feeding rollers start to spin } \\
\text { and ends right before a given cross-cut is made }\end{array}$ \\
\hline Tree bucking & $\mathrm{tb}\left(\mathrm{t}_{\mathrm{tb}}\right)$ & $\begin{array}{l}\text { The effective tree cross-cutting made in order to detach the logs from the } \\
\text { tree. Begins when the sawdust starts to be expelled and ends when the } \\
\text { log detaches from the stem }\end{array}$ \\
\hline $\begin{array}{l}\text { Processing the } \\
\text { tree top }\end{array}$ & $\mathrm{ptt}\left(\mathrm{t}_{\mathrm{ptt}}\right)$ & $\begin{array}{l}\text { An additional combination of boom movements, delimbing and cross- } \\
\text { cutting to further fragment the tree-tops. Begins when the last } 4 \text { meter } \\
\text { log is detached and ends when the last portion of the tree-top is dropped } \\
\text { from the processor head }\end{array}$ \\
\hline $\begin{array}{l}\text { Head } \\
\text { recalibration }\end{array}$ & $\mathrm{hr}\left(\mathrm{t}_{\mathrm{hr}}\right)$ & $\begin{array}{l}\text { A work (time) element required in order to realign the computer } \\
\text { measurement system to the processed tree. Begins when the processor } \\
\text { head moves towards the end of the stem in order make a cross-cut and } \\
\text { ends when the that cross-cut has been made }\end{array}$ \\
\hline Harvester cycle & $\mathrm{HC}(\mathrm{HCT})$ & A work-cycle summing up the above described work (time) elements. \\
\hline \multicolumn{3}{|l|}{ Forwarder } \\
\hline Empty turn & et $\left(t_{\mathrm{et}}\right)$ & $\begin{array}{l}\text { The effective movements of the machine without any load. Begins when } \\
\text { the machine starts moving from the roadside and ends when the machine } \\
\text { stops within the felling block in order to load }\end{array}$ \\
\hline $\begin{array}{l}\text { Logs arranging } \\
\text { in the bunk }\end{array}$ & lab $\left(\mathrm{t}_{\mathrm{lab}}\right)$ & $\begin{array}{l}\text { The effective empty and loaded movements of the crane. Begins when } \\
\text { the crane moves from the bunk towards the wood pile and ends when } \\
\text { the bunk if fully loaded, excluding inter-pile moving. A repetitive work } \\
\text { element within the same turn and for several stops along the wood piles. } \\
\text { Supplementary maneuvers aiming to improve the position of logs into the } \\
\text { bunk. Repeated for most of the forwarding work cycles, it complemented } \\
\text { the loading. Begins with the first maneuver of the grapple aiming to } \\
\text { relocate logs and ends when starting to carry on other maneuvers such as } \\
\text { inter-pile moving or loading }\end{array}$ \\
\hline
\end{tabular}


Table 2 (continuation)

\begin{tabular}{|c|c|c|}
\hline $\begin{array}{l}\text { Inter-pile } \\
\text { moving }\end{array}$ & $\operatorname{ipm}\left(t_{\text {ipm }}\right)$ & $\begin{array}{l}\text { The effective movements between the piles. Begins when the machine } \\
\text { starts to move from the current loading position and ends with the } \\
\text { machine stopping to the next log pile. }\end{array}$ \\
\hline Loaded turn & lt $\left(\mathrm{t}_{1 \mathrm{t}}\right)$ & $\begin{array}{l}\text { The effective machine movement after full loading and arranging of } \\
\text { wood in the bunk. Begins when the machine starts moving and ends } \\
\text { when the machine firstly stops at the roadside. }\end{array}$ \\
\hline Unloading & $\mathrm{u}\left(\mathrm{t}_{\mathrm{u}}\right)$ & $\begin{array}{l}\text { The effective unloading and (or) transbordation of wood from the bunk } \\
\text { to the wood stack or into truck trailers using the forwarder's crane. } \\
\text { Begins with the forwarder's first stop at the roadside near a stack or a } \\
\text { truck and ends when the last piece of wood is delivered into stack or into } \\
\text { the truck's trailer }\end{array}$ \\
\hline $\begin{array}{l}\text { Logs arranging } \\
\text { at the roadside }\end{array}$ & $\operatorname{lar}\left(\mathrm{t}_{\mathrm{lar}}\right)$ & $\begin{array}{l}\text { Supplementary maneuvers aiming to improve the position of logs into } \\
\text { the stacks and (or) trailers. Repeated for most of the forwarding work } \\
\text { cycles, it complemented the unloading. Begins with the first maneuver } \\
\text { of the grapple aiming to relocate logs and ends when starting to carry on } \\
\text { other maneuvers such as the empty turn }\end{array}$ \\
\hline Miscellaneous & $\mathrm{m}\left(\mathrm{t}_{\mathrm{m}}\right)$ & $\begin{array}{l}\text { Different less important and less repetitive maneuvers that were not } \\
\text { specifically separated }\end{array}$ \\
\hline $\begin{array}{l}\text { Forwarder } \\
\text { Cycle }\end{array}$ & $\mathrm{FC} \mathrm{(FCT)}$ & A work-cycle summing up the above described work (time) elements \\
\hline $\begin{array}{l}\text { Forwarding } \\
\text { Delays }\end{array}$ & FD (TFD) & All actions that resulted in technical, operational and personal delays \\
\hline
\end{tabular}

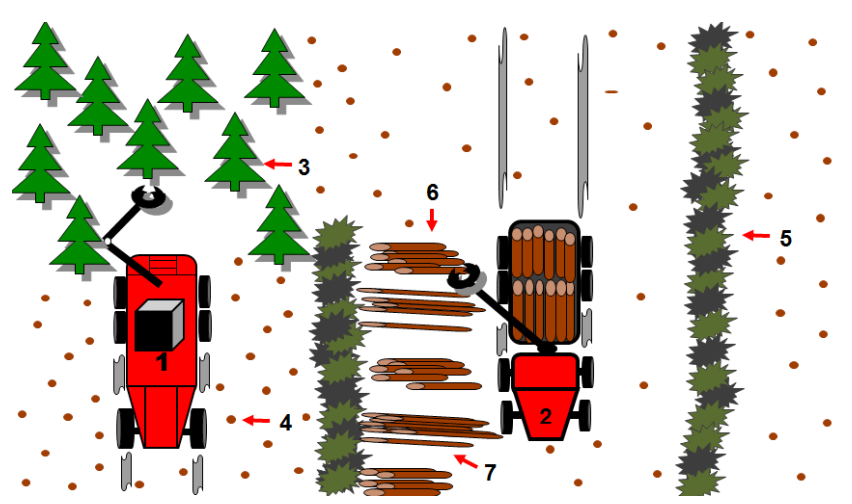

Figure 1 Work pattern of the studied harvesting system. Legend: 1 - harvester, 2 - forwarder, 3 - tree to be removed, 4 stump, 5 - pile of harvesting slash including firewood, 6 - pile of 3 meter in length logs, 7 - pile of 4 meter in length logs.

rate fashion, it did not allow the computation of gross production rate. The forwarding time consumption data was collected using an Algiz 7 handheld computer equipped with time studying software - Time Study Software v.1.
The operational variables used in this study were either directly collected in the field or derived in the office part of the study. A Garmin 62stc GPS (Global Positioning System) receiver unit was attached to forwarder's cab in order to collect the data needed to estimate the travelled distance. At the end of each work day, the recorded track-logs were transferred into a personal computer as GPS Exchange files (GPX). This approach was used to collect data for a total number of 126 forwarding turns. The number of loaded logs as well as the assortment category and load type $(3,4 \mathrm{~m}$ or mixed) were visually evaluated and introduced in the portable computer as comments for each of the analyzed forwarding turns. Given the speed at which the operations were carried out, a detailed esti- 
mation of volume per tree or per resulted logs was not possible. However, this study assumed less variability in the same category due to the fact that the harvested stand was an even-aged monoculture. To this end, measurements were carried out in order to get the mean volume of each assortment category. A number of 220 logs having $3 \mathrm{~m}$ in length and a number of $212 \operatorname{logs}$ having $4 \mathrm{~m}$ in length were randomly sampled. Their end diameters were measured and their over-bark (o.b.) volume was computed. Fuel consumption data was collected for a number of 11 days by placing the machines on a perfectly flat area near the roadside prior and after the daily operations and reading the daily initial and final fuel levels on the on-board computers. Also, readings were made on the daily working hours and the covered distance. In addition, the daily processed volume was extracted from the harvester's computer. These data were summarized in MS Excel sheets in the office phase of the study.

\section{Data processing}

An AviX Method software trial license (Sölme $\mathrm{AB}$, Sweden) was used to analyze the harvester's video data. By using this software application, it was possible to separate time elements using a sub-second accuracy as well as to comment the separated time elements. Also, the software features data export to MS Excel files, a functionality that was used to produce an initial database. Further refining and processing was necessary as the video files were analyzed at the most possible detail and the elemental time durations were produced for every processed tree group, tree and log respectively. The analysis of video files enabled the extraction of operational variables such as the number of harvested trees per one machine movement, the number of recovered logs (NPL) categorized in 3 (NL3M) and 4 $\mathrm{m}$ (NL4M) for each tree, as well as the estimated commercial length (CL). Further computations used strict values of 3 and 4 meters for the component logs. The commercial vol- ume $(\mathrm{CV})$ of each tree (o.b. $\mathrm{m}^{3}$ ) was derived based on the number of logs per tree falling within each assortment category. A number of 27.5 field recorded hours were analyzed in this study. Forwarder time and production data was processed after saving it into a MS Excel workbook. The number of loaded logs per turn (NL) and the type of loaded assortments were derived from the field comments while the forwarded volume per turn (FV) was estimated based on the number of logs within a load, their particular assortment category and the mean volume determined for each assortment category. Forwarding distance (FD) was extracted from GPS data using the Global Mapper software to delineate and calculate the total and mean forwarding distance per turn. Those forwarding turns that showed obvious errors related to positioning accuracy were excluded from the analysis (Figure 2) resulting in a number of 61 valid turns.

\section{Statistical analysis and estimates of perfor- mance indicators}

A statistical design was developed based on the concepts, guidelines and examples described in Acuna et al. (2012). Here, the aim was to estimate some of the objective performance indicators of the studied harvesting system as well as to model the dependence of response variables such as the time consumption in relation to the variation of some selected operational variables. A first step involved an estimation of the basic descriptive statistics of dependent and independent variables using for this purpose the capabilities and functionalities of MS Excel software. The statistical procedures and techniques of ordinary least square simple and multiple regression were used to build the time consumption models for the studied machines. Both, global and predictor level significance tests were conducted using the $p$ values $(p \leq 0.01)$ as significance thresholds (Acuna et al., 2012). This modelling approach was used to derive delay-free cycle time consumption models for the studied ma- 


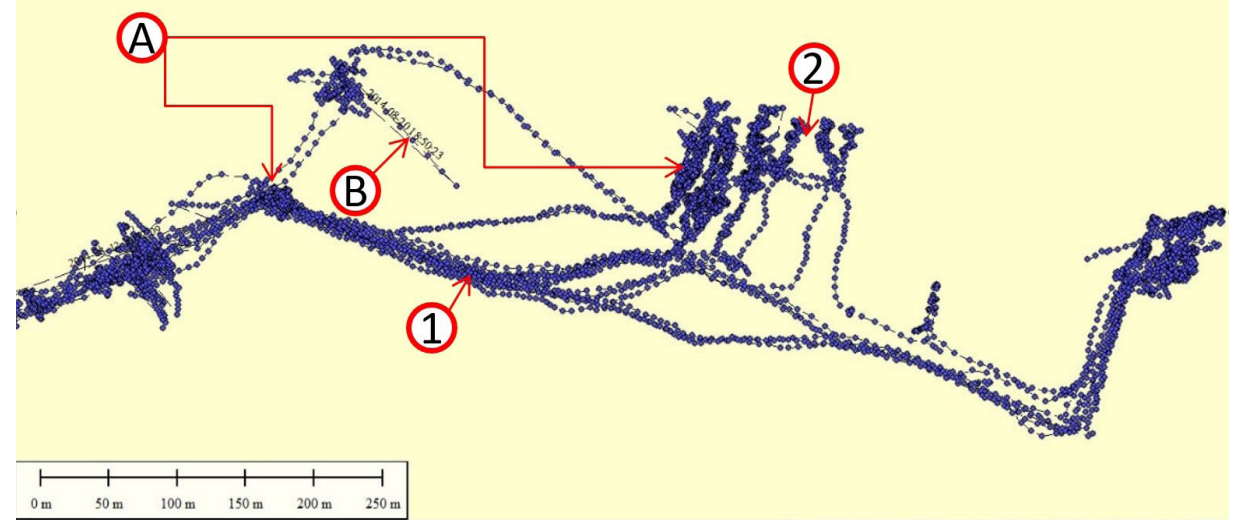

Figure 2 A snapshot of the environment used to collect and analyze forwarding data. Legend: 1 main forwarding path, 2 - harvesting strip, A - a typical example of accurate data, B - a typical example of accuracy loss

chines as well as to emphasize the dependence relations between some variable pairs aiming to describe the operational behaviors. In order to develop the descriptive statistics and models, the original data that was contained in the databases needed some additional refining. For instance, from the harvester data pool, some of the observations were excluded as they failed to accurately describe an analyzed work cycle. This was the case of observations located at the beginning of a given video file where the researcher that analyzed the data had difficulties in correctly attributing given analyzed trees to a reference period that included also a previous movement made by the machine to reach the trees in question. Similar issues were specific to data portions located at the end of some video files, a case where the researcher was not sure if additional trees would have been harvested for a given movement of the machine to reach a tree group.

\section{Results}

\section{Time consumption}

Table 3 shows the relevant descriptive statis234 tics of time consumption and operational variables. A number of 1045 trees were the subject of analysis. Moving between the tree groups to be harvested occurred 252 times meaning that, in average, $4.15 \pm 2.63$ trees were harvested per one machine movement a fact that was translated into $3.32 \pm 3.18$ seconds spent per harvested tree in this work element. Swinging to fell was clearly separated only 944 times. A delay-free tree felling and processing work cycle took, in average $48.69 \pm 13.69$ seconds. In the time consumption structure, notable were tree delimbing (43.49\%), swinging to process $(10.94 \%)$ and swinging to fell $(10.14 \%)$ work elements. Also, supplementary tree top processing was accountable for a share of almost $9 \%$ of the delay free time consumption. Head recalibration was required in 69 cases and it took, in average, less than 2 seconds. In average, $4.35 \pm 0.89 \operatorname{logs}$ were recovered from each harvested tree, out of which the 3-meter m logs were dominant $(3.39 \pm 0.99)$. The cumulated commercial length of the recovered logs varied between 3 and 26 meters averaging about $14 \mathrm{~m}$ per tree resulting in a commercial volume that varied between 0.044 and 0.676 $\mathrm{m}^{3}$, averaging $0.36 \pm 0.11 \mathrm{~m}^{3}$ per tree. In Figure 3 are given the fitted models that were 
Table 3 Descriptive statistics of the studied harvesting system

\begin{tabular}{|c|c|c|c|c|c|c|}
\hline \multirow{2}{*}{$\begin{array}{l}\text { Studied machine } \\
\text { HARVESTER }\end{array}$} & \multicolumn{6}{|c|}{ Descriptive statistics } \\
\hline & $\mathrm{N}$ & SUM & Min & Max & Mean \pm St. Dev. & $\%$ \\
\hline \multicolumn{7}{|c|}{ Separated work elements and the abbreviation of time expenditure variable } \\
\hline $\begin{array}{l}\text { Moving to (between) tree groups to } \\
\text { be harvested }-t_{m t g}(\mathrm{~s})\end{array}$ & 252 & 3470.318 & 0.316 & 41.200 & $3.320 \pm 3.180$ & 6.82 \\
\hline Swing to fell $-t_{s f}(\mathrm{~s})$ & 944 & 5158.100 & 1.000 & 24.400 & $5.460 \pm 2.710$ & 10.14 \\
\hline Tree securing $-t_{t s}(\mathrm{~s})$ & 1039 & 4638.000 & 0.200 & 21.000 & $4.460 \pm 2.040$ & 9.12 \\
\hline Felling cut $-t_{f c}(\mathrm{~s})$ & 1042 & 2200.200 & 0.300 & 20.600 & $2.110 \pm 1.510$ & 4.32 \\
\hline Swing to process $-t_{s p}(\mathrm{~s})$ & 1036 & 5564.700 & 1.500 & 52.100 & $5.370 \pm 3.470$ & 10.94 \\
\hline Tree delimbing $-t_{t d}(\mathrm{~s})$ & 1045 & 22129.200 & 2.500 & 95.800 & $21.180 \pm 8.950$ & 43.49 \\
\hline Tree bucking $-t_{t b}(\mathrm{~s})$ & 1045 & 3132.300 & 0.100 & 8.300 & $3.000 \pm 1.210$ & 6.16 \\
\hline Processing the tree top $-t_{p t t}(\mathrm{~s})$ & 1030 & 4482.910 & 0.900 & 22.100 & $4.350 \pm 2.390$ & 8.81 \\
\hline Head recalibration $-t_{h r}(\mathrm{~s})$ & 69 & 118.400 & 0.400 & 11.800 & $1.720 \pm 1.840$ & 0.23 \\
\hline $\begin{array}{l}\text { Delay free harvesting cycle time - } \\
H C T(\mathrm{~s})\end{array}$ & 1045 & 50880.908 & 17.550 & 128.880 & $48.690 \pm 13.690$ & 100.00 \\
\hline \multicolumn{7}{|l|}{ Operational variables } \\
\hline Total no. of recovered logs - NPL & 4546 & - & 1.000 & 8.000 & $4.350 \pm 0.890$ & 100.00 \\
\hline $\begin{array}{l}\text { No. of } 3 \mathrm{~m} \text { in length recovered logs } \\
-N L 3 M\end{array}$ & 3223 & - & 1.000 & 6.000 & $3.390 \pm 0.990$ & 70.90 \\
\hline $\begin{array}{l}\text { No. of } 4 \mathrm{~m} \text { in length recovered logs } \\
-N L 4 M\end{array}$ & 1323 & - & 1.000 & 4.000 & $1.400 \pm 0.680$ & 29.10 \\
\hline Commercial length - $C L(\mathrm{~m})$ & - & - & 3.000 & 26.000 & $14.320 \pm 2.510$ & - \\
\hline Commercial volume - $C V\left(\mathrm{~m}^{3}\right)$ & 1045 & 374.066 & 0.044 & 0.676 & $0.360 \pm 0.110$ & - \\
\hline \multicolumn{7}{|l|}{ FORWARDER } \\
\hline \multicolumn{7}{|c|}{ Separated work elements and the abbreviation of time expenditure variable } \\
\hline Empty turn $-t_{e t}(\mathrm{~s})$ & 126 & 46064 & 50 & 742 & $365.59 \pm 162.26$ & 15.95 \\
\hline Loading $-t_{l}(\mathrm{~s})$ & 126 & 79548 & 401 & 1114 & $631.33 \pm 143.15$ & 27.55 \\
\hline Logs arranging in the bunk $-t_{l a b}(\mathrm{~s})$ & 122 & 12828 & 9 & 301 & $105.15 \pm 61.38$ & 4.44 \\
\hline Inter-pile moving $-t_{i p m}(\mathrm{~s})$ & 124 & 20291 & 17 & 958 & $163.64 \pm 124.17$ & 7.03 \\
\hline Loaded turn $-t_{l t}(\mathrm{~s})$ & 126 & 60900 & 95 & 1008 & $483.33 \pm 196.45$ & 21.09 \\
\hline Unloading $-t_{u}(\mathrm{~s})$ & 125 & 47294 & 158 & 1013 & $378.35 \pm 161.11$ & 16.38 \\
\hline Logs arranging at the roadside $-t_{\text {lar }}(\mathrm{s})$ & 108 & 12703 & 4 & 701 & $117.62 \pm 145.54$ & 4.40 \\
\hline Miscellaneous $-t_{m}(\mathrm{~s})$ & 92 & 9154 & 3 & 1092 & $99.50 \pm 185.25$ & 3.17 \\
\hline $\begin{array}{l}\text { Delay free forwarding cycle time - } \\
F C T \text { (s) }\end{array}$ & 126 & 288782 & 1114 & 3616 & $2291.92 \pm 598.29$ & 100.00 \\
\hline Delays - TD (s) & - & 71127 & - & - & - & 19.76 \\
\hline Workplace time - $T T(\mathrm{~s})$ & - & 359909 & - & - & - & 100.00 \\
\hline \multicolumn{7}{|l|}{ Operational variables } \\
\hline No. of $3 \mathrm{~m}$ in length loads $-L 3 M$ & 69 & - & - & - & 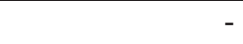 & 55.20 \\
\hline No. of $4 \mathrm{~m}$ in length loads $-L 4 M$ & 47 & - & - & - & - & 37.60 \\
\hline No. of mixed loads - $L$ & 9 & - & - & - & - & 7.20 \\
\hline No. of $3 \mathrm{~m}$ forwarded logs - NL3M & & 11750 & 45 & 191 & $150.640 \pm 30.220$ & - \\
\hline No. of $4 \mathrm{~m}$ forwarded logs - NL $4 M$ & & 8478 & 40 & 213 & $151.390 \pm 37.240$ & - \\
\hline Total no. of forwarded logs - NL & & 20218 & 75 & 294 & $161.740 \pm 22.170$ & - \\
\hline Forwarding distance $-F D(\mathrm{~m})$ & 61 & 29242 & 152 & 873 & $479.337 \pm 205.664$ & - \\
\hline Forwarded volume $-F V\left(\mathrm{~m}^{3}\right.$ o.b. $)$ & 125 & 1524.532 & 3.300 & 18.718 & $12.200 \pm 4.300$ & - \\
\hline
\end{tabular}


found to be significant in expressing the time consumption of given work elements in relation to selected operational variables. The $t_{t d}$ variable was explained in a proportion of about $46 \%$ by the commercial length (CL) when using an exponential fitting. For this model, it was assumed that from the measured and (or) derived independent variables, the commercial length would best explain the process mechanics. The variation of $t_{t b}$ variable was explained in a proportion of about $73 \%$ by the variation of NPL. In this last case, a quadratic
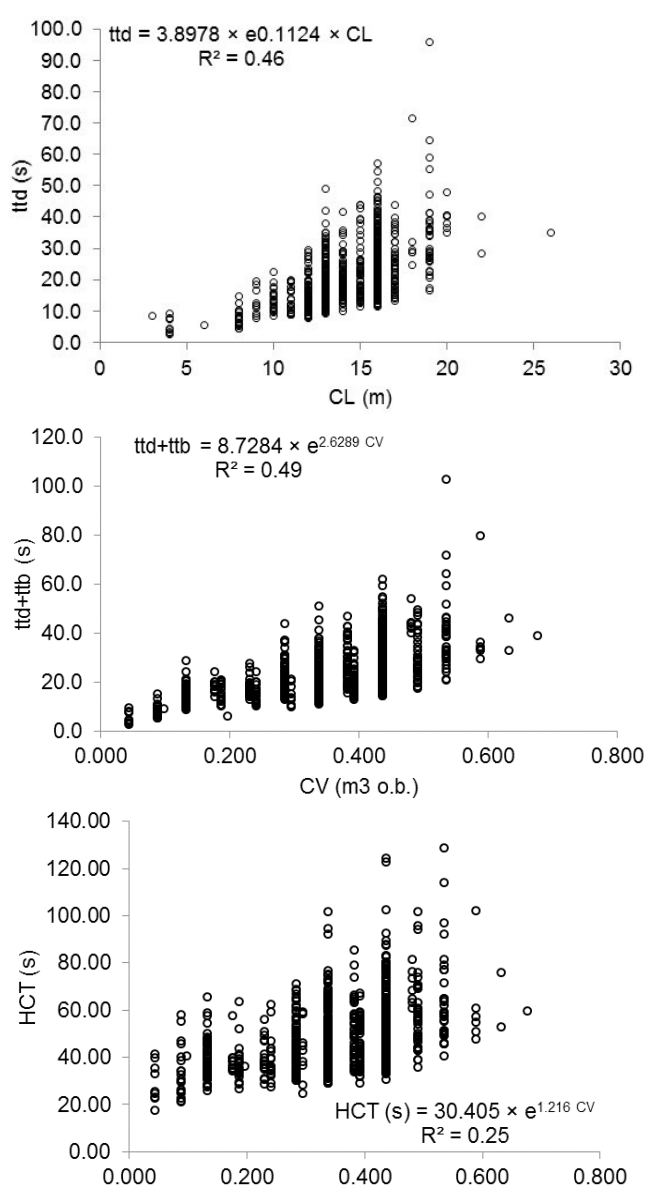

Figure 3 Relation between the time consumption of selected work elements and selected operational variables. Legend: $\mathrm{ttd}$ - tree delimbing time, $\mathrm{ttb}$ - tree bucking time, CL - commercial length, NPL - no. of processed logs, CV - commercial volume. function provided the best fit assuming that, in the absence of diameters at the cuts levels, the number of cuts respectively the number of recovered logs would best explain the process mechanics. The time consumption variation of the two mentioned work elements $\left(\mathrm{t}_{\mathrm{td}}+\mathrm{t}_{\mathrm{tb}}\right)$ was explained in a proportion of about $49 \%$ by the variation of commercial volume (CV) using an exponential fit as here the commercial volume included both, the variation effects of the commercial length and number of processed logs. For the same reasons, the commercial volume (CV) was chosen as a predictor when developing the model for the delay-free tree felling and processing time consumption (HCT). No attempts were made to fit a multiple regression model for the HCT since the NPL, CL and CV variables were strongly correlated each other. Instead, the $\mathrm{CV}$ and an exponential fit seemed to give the best results (Figure 4). Table 3 summarizes the relevant descriptive statistics of forwarding operations. As shown, the delays (TD) accounted for about $20 \%$ of the workplace time (TT). In a delay-free forwarding work cycle (FCT), loading $\left(\mathrm{t}_{1}\right)$ accounted for the greatest share $(27.55 \%)$ being followed by the loaded turn $\left(\mathrm{t}_{\mathrm{lt}}\right)-(21.09 \%)$, unloading $\left(\mathrm{t}_{\mathrm{u}}\right)$ - $(16.38 \%)$ and the empty turn $\left(\mathrm{t}_{\mathrm{et}}\right)$ - $(15.95 \%)$. Logs arranging in the bunk $\left(\mathrm{t}_{\text {lab }}\right)$ as well as the logs arranging in stacks or into trailers $\left(\mathrm{t}_{\text {lar }}\right)$ accounted for similar shares (4.44 and $4.40 \%$ ). The number of loads composed solely of 3-meter logs (L3M) was of 69. A number

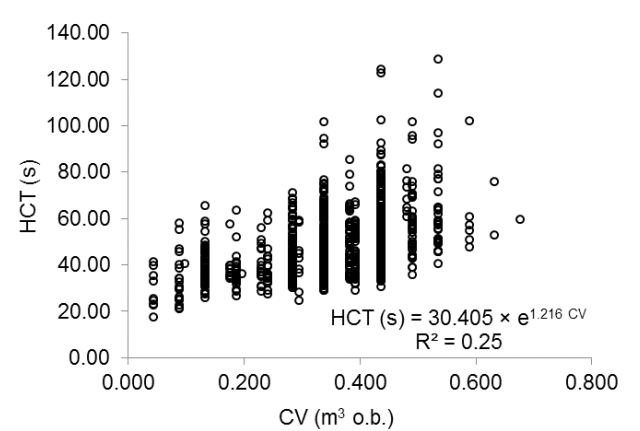

Figure 4 Relation between the delay-free harvesting cycle time (HCT) and the commercial volume $(\mathrm{CV})$ 
of 47 loads were composed of 4-meter logs (L4M) and a number of 9 loads were mixed (L). 20,218 logs (NL) were forwarded during the study, out of which 11,750 had 3 meters in length (NL3M). In average, about 162 logs were forwarded per turn. The forwarded volume was estimated to about $1524 \mathrm{~m}^{3}$ meaning an average volume forwarded per turn of about $12 \mathrm{~m}^{3}$. It differed by the felled and processed volume due to the smaller sample size in case of the harvester. The forwarding distance varied between 152 and $873 \mathrm{~m}$, averaging about $479 \mathrm{~m}$. Strong evidences indicating the time consumption variation of some work elements in relation to forwarding distance (FD) were found. Moving time (MT) that was computed for each turn by summing all the time elements that involved machine movements, was highly dependent $\left(\mathrm{R}^{2}=0.80\right)$ on the moving distance (D) as shown in Figure 5. The variation of both, the empty $\left(\mathrm{t}_{\mathrm{et}}\right)$ and loaded $\left(\mathrm{t}_{\mathrm{tt}}\right)$ turns, was fitted through linear equations as a function of forwarding distance (FD). The estimation results are shown in Figure 6. The empty turn that took, in average, less time than the loaded turn (Table 3), showed a similar behavior in relation to forwarding distance (Figure 6 ). The determination coefficients indicated a goodness to fit of about $77 \%$ in case of $t_{\text {et }}$ FD relation respectively of $68 \%$ in the case of $\mathrm{t}_{\text {It }}$ - FD relation. The dependence between the delay-free forwarding cycle time (FCT), forwarding distance (FD) and the forwarded volume per turn (FV) is shown in Table 4.

\section{Productivity and fuel consumption}

For the studied conditions, tree felling and processing net production rate $\left(\mathrm{NPR}_{\mathrm{TFP}}\right)$ was estimated at $26.47 \mathrm{~m}^{3}$ o.b. $\cdot \mathrm{h}^{-1}$, meaning that, in average, about 74 trees were felled and fully processed per hour (322 logs recovered per hour). In Table 5 is given an overview on the estimated productive performance indicators

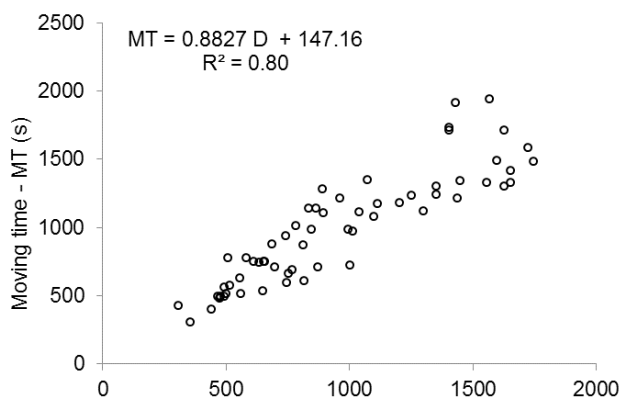

Figure 5 Relation between the forwarder's moving time (MT) and the travelled distance (D)

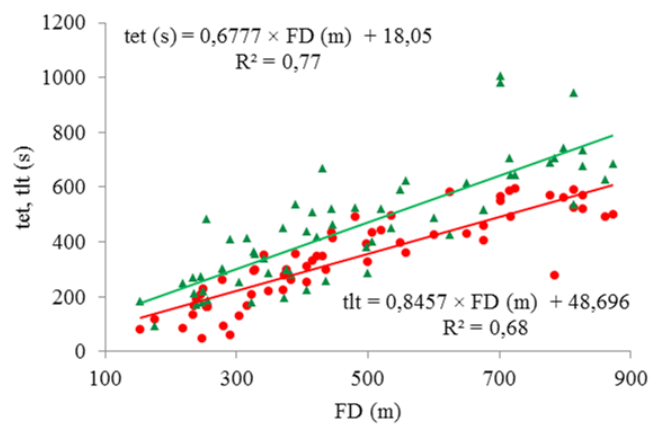

Figure 6 Relation between the empty turn (tet) and the loaded turn (tlt) time consumption, respectively, and the forwarding distance (FD)

Table 4 Estimated linear regression models for tree felling, processing and forwarding operations

\begin{tabular}{lrlllll}
\hline $\begin{array}{l}\text { Linear time consumption models for the delay-free work cycles } \\
\text { in tree felling, processing and forwarding operations }\end{array}$ & \multicolumn{2}{c}{$R^{2}$} & Sig. $F$ & \multicolumn{2}{l}{ Predictor } & $p$ \\
\hline$H C T(\mathrm{~s})=57.120 \cdot C V\left(\mathrm{~m}^{3}\right.$ o.b. $)+28.243$ & 1045 & 0.20 & $<0.001$ & $\mathrm{CV}$ & $<0.001$ \\
$F C T(\mathrm{~s})=100.447 \cdot F V\left(\mathrm{~m}^{3}\right.$ o.b. $)+1.522 \cdot F D(\mathrm{~m})+397.773$ & 61 & 0.70 & $<0.001$ & $F D$ & $<0.001$ \\
& & & & $F V$ & $<0.001$ \\
\hline
\end{tabular}

Note. Abbreviations: $N$ - no. of observations, $R^{2}$ - coefficient of determination, Sig. $F$ - results of global significance test, $p$ - results of predictor significance tests, HCT - delay free harvesting cycle time, $\mathrm{CV}$ - commercial volume, FCT - delay free forwarding cycle time, FV - forwarded volume, FD - forwarding distance. 
of the studied harvesting system. Tree felling and processing net production rate varied as a function of produced commercial volume (Figure 7). The forwarding net production rate $\left(\mathrm{F}_{\mathrm{NPR}}\right)$ was estimated at $19.16 \mathrm{~m}^{3}$ o.b. $\cdot \mathrm{h}^{-1}$. Under the assumption of no delays, about 252 logs would have been extracted per hour to the roadside. Based on those forwarding turns for which the load volume and forwarding distance data were available, a dependence relation between the forwarding net production rate $\left(\mathrm{NPR}_{\mathrm{F}}\right)$ and the forwarding distance was developed (Figure 8). Fuel consumption statistics are given in Table 6 . The hourly fuel consumption in the harvester's case was estimated to about 211 resulting in a unit fuel consumption of about $1.11 \cdot \mathrm{m}^{-3}$ o.b. The delivery of one cubic meter of wood to the roadside meant, in average, a harvesting system's fuel consumption of about 1.71 .

\section{Discussion}

Based on the research that points out the rationale of deriving local estimates (Hiesl \& Benjamin 2013), the aim of this study was to investigate the performance of a mid-sized cut-to-length harvesting system that integrated the recovery of fuelwood. According to this study, the delivery of sawmill and pulpwood assortments to the roadside can be interpreted as being technically limited by the forwarding operations performance. About 0.05 hours were required to deliver one cubic meter of wood to the roadside. Under the assumption of no delays, the forwarder would have been matched the harvester productivity for a mean extraction distance of about $100 \mathrm{~m}$. From this point of view, the time consumption for the supplementary processing of tree-tops can be interpreted as having no effect on the operational performance of the studied system, en-

Table 5 Indicators of productive performance of the studied harvesting system

\begin{tabular}{llllllll}
\hline $\begin{array}{l}\text { Machine } \\
\text { type }\end{array}$ & $\begin{array}{l}\text { Workplace } \\
\text { time }(\mathrm{h})\end{array}$ & $\begin{array}{l}\text { Delay free } \\
\text { time }(\mathrm{h})\end{array}$ & $\begin{array}{l}\text { Estimated } \\
\text { production } \\
\left(\mathrm{m}^{3} \text { o.b. }\right)\end{array}$ & $\begin{array}{l}G P R \\
\left(\mathrm{~m}^{3} \text { o.b.h }\right)\end{array}$ & $\begin{array}{l}\text { NPR } \\
\left(\mathrm{m}^{3} \text { o.b. h) }\right)\end{array}$ & $\begin{array}{l}G E(\mathrm{hrs} \\
\left.\mathrm{m}^{-3} \text { o.b. }\right)\end{array}$ & $\begin{array}{l}N E\left(\mathrm{hrs} \mathrm{m}^{-3}\right. \\
\text { o.b. })\end{array}$ \\
\hline $\begin{array}{l}\text { Harvester } \\
(T F P)\end{array}$ & - & 14.134 & 374.066 & - & 26.466 & - & 0.038 \\
\hline $\begin{array}{l}\text { Forwarder } \\
(F)\end{array}$ & 99.319 & 79.561 & 1524.530 & 15.350 & 19.162 & 0.065 & 0.052 \\
\hline
\end{tabular}

Note. Abbreviations: GPR - gross production rate, NPR - net production rate, GE - gross efficiency, NE - net efficiency, TFP - tree felling and processing, F - forwarding.

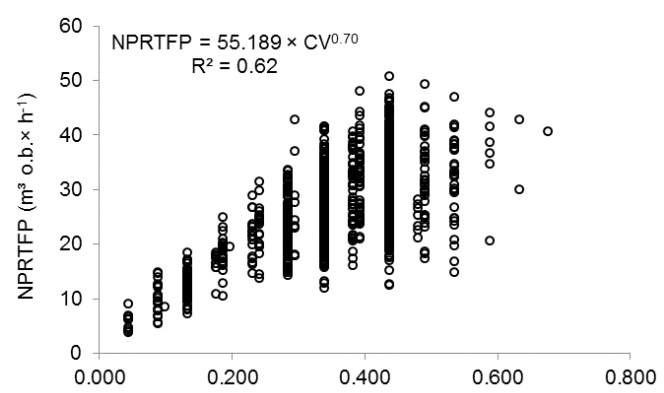

Figure 7 Relation between the tree felling and processing net production rate (NPRTFP) and the variation of commercial volume $(\mathrm{CV})$

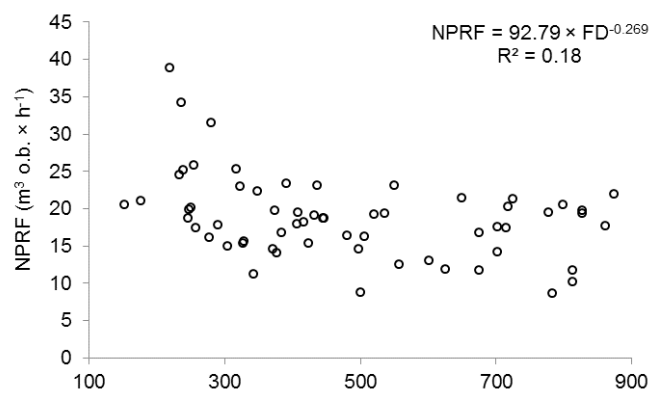

Figure 8 Relation between the forwarding net production rate (NPRF) and the variation of forwarding distance (FD) 
Table 6 Fuel consumption statistics of the studied harvesting system

\begin{tabular}{lccccc}
\hline $\begin{array}{l}\text { Machine } \\
\text { type }\end{array}$ & $\begin{array}{l}\text { Estimated } \\
\text { production } \\
\left(\mathrm{m}^{3} \mathrm{o} . \mathrm{b} .\right)\end{array}$ & $\begin{array}{l}\text { Engine } \\
\text { working } \\
\text { hours }(\mathrm{h})\end{array}$ & $\begin{array}{l}\text { Total fuel } \\
\text { consumption }(\mathrm{l})\end{array}$ & $\begin{array}{l}\text { Hourly fuel } \\
\text { consumption } \\
\left(\mathrm{l} \mathrm{h}^{-1}\right)\end{array}$ & $\begin{array}{l}\text { Unit fuel } \\
\text { consumption } \\
\left(\mathrm{l} \mathrm{m}^{-3} \mathrm{o} . \mathrm{b} .\right)\end{array}$ \\
\hline Harvester & $1381.89^{*}$ & 74.40 & 1565.10 & 21.04 & 1.133 \\
Forwarder & 1524.53 & 79.00 & 879.80 & 11.14 & 0.577 \\
\hline
\end{tabular}

Note: * Based on on-board computer

abling also a partial recovery of wood for energy. The delivery of one cubic meter of wood to the roadside meant a fuel consumption of about 1.71 , including here also engine running during non-productive tasks. From this point of view, the studied harvesting system showed an increased operational performance since some of the alternative harvesting systems, even if using smaller engines, are less productive and often result in higher fuel consumptions. For instance, Popovici (2013) concluded that full recovery of firewood assortments from trees that were smaller if compared to those from this study would require about 0.41 of fuel per cubic meter when using a small chainsaw. Furthermore, Vusić et al. (2013) showed that, in extractions less intensive than that from this study, the fuel consumption per one cubic meter of timber may be as high as 0.8 to $1.8 \mathrm{~kg}$ in skidding operations implemented under conditions of shorter distances than that reported by this study. One of the greatest advantages of using harvester-forwarder systems resides in their capability to quickly remove affected wood, giving this way the opportunity to still recover, in a timely manner, timber for different purposes which otherwise would be lost or sub-classified. It is known that the production rate of tree felling and processing using harvesters exhibits a peaking behavior that is dependent on the tree size variation (Visser \& Spinelli 2011). In this study, the net production rate of tree felling and processing was of about $26 \mathrm{~m}^{3} \cdot \mathrm{h}^{-1}$, a result that is comparable with those reported by Gerasimov et al. (2012) under the assumption that the volume of production would be reduced in this study by excluding the bark. Glöde \& Sikström (2001) investigated the operational and environmental 239 performance of two harvesting methods for a single-grip harvester. The results of their study indicate production rates in range of $26-27 \mathrm{~m}^{3}$ $\cdot \mathrm{h}^{-1}$, including here the delays accounting for less than 15 minutes within an hour. In their study, the tree size was similar to that from herein, but the extraction system was less intensive, a fact that could lead to the assumption that the net production rate in this study should have been greater. However, the supplementary tree top processing affected in this study the net production rate by a contribution of $9 \%$ in the delay-free time consumption. Assuming that this work element would not have been carried out, under same circumstances, the productivity rate would have been increased to about $29 \mathrm{~m}^{3} \cdot \mathrm{h}^{-1}$. Also, this study reports the net production rate based on the production output, excluding the volume of the tree-tops. Given its proportion in the time consumption, the supplementary tree top processing affected also the fuel consumption rate which was of about $211 \cdot \mathrm{h}^{-1}$ in this study. However, depending on the engine power, such figures may reach as high as $24.3 \mathrm{l} \cdot \mathrm{h}^{-1}$ (Holzleitner et al. 2011). Similar to other studies carried out on forwarding operations (Spinelli et al. 2004, Nurminen et al. 2006, Spinelli \& Magagnotti 2010, Ghaffarian et al. 2007), in this study, the forwarding performance was significantly affected by the operational distance and the amount of extracted wood per turn. Also, delays affected in a negative way the forwarding productivity. They accounted for a share that was, somehow, similar to other studies such as those conducted by Dvořák and Behjou (2011), Stankić et al. (2012) respectively Ghaffarian et al. (2007) who reported delays in range of 17 to $26 \%$, but they were significantly 
smaller than those characterizing the skidding operations (e.g., Borz et al. 2013). Nevertheless, the net production rate was of about $19 \mathrm{~m}^{3}$ $\cdot \mathrm{h}^{-1}$. It can be speculated here that the estimated forwarding net production rate can be explained in a greater proportion by the average load per turn and less by the mean extraction distance. For instance, Ghaffarian et al. (2007) reported a net production rate of about $18 \mathrm{~m}^{3}$. $\mathrm{h}^{-1}$ in conditions of a mean extraction distance of about $100 \mathrm{~m}$. However, in their study, the mean load per turn was of about $10 \mathrm{~m}^{3}$. Similar to the majority of reported results, the effective loading and wood arranging into the bunk were the most time-consuming work elements (almost $32 \%$ of the delay-free work time). While we did not investigate the effect that the number of assortments may have on the time consumption for loading and unloading the wood, it is possible that this variable had an effect as more recently proven by Manner et al. (2013), Stankić et al. (2012) and Nurminen et al. (2006). Loaded turn took, in average, more time than the empty turn. Assuming equal moving distances for the two, the moving speed was of about $3.80 \mathrm{~km} \cdot \mathrm{h}^{-1}$ for the loaded turn and of about $5.00 \mathrm{~km} \cdot \mathrm{h}^{-1}$ for the empty turn, results that are comparable with those reported for Croatian mid-sized, good soil bearing capacity forwarding operations (Stankić et al., 2012) and somehow greater than those reported by Nurminen et al. (2006). In this study, the fuel consumption in forwarding operations assumed all the engine-running time. The results indicate a mean hourly fuel consumption of 11.141 which is similar to results reported by other studies (Holzleitner et al. 2011, Danilović et al. 2014).

\section{Conclusions}

While this work addressed mainly the effect of supplementary tree processing on the performance of studied harvesting system, it is important to keep in mind that the productive performance may be affected by the operators' skills and experience, weather conditions as well as significant variations of other operational factors. The reported results point out that the integration of sawmill, pulpwood and fuelwood recovery affects the harvester's performance by a reduction of NPR of about $2.5 \mathrm{~m}^{3} \cdot \mathrm{h}^{-1}(9 \%)$. Nevertheless, under the assumption of using locally available extraction equipment for the fuelwood, the production rate reduction did not affect the productive performance of studied harvesting system for extraction distances greater than $100 \mathrm{~m}$.

\section{Bibliography}

Acuna M., Bigot M., Guerra S., Hartsough B., Kanzian C., Kärhä K., Lindroos O., Magagnotti N., Roux S., Spinelli R., Talbot B., Tolosana E., Zormaier F., 2012. Good practice guidelines for biomass production studies. CNR IVALSA Sesto Fiorentino: 51.

Bell J. L., 2001. Changes in logging injury rates associated with use of feller-bunchers in West Virginia. Proceedings of the International Mountain Logging and 11th Pacific Northwest Skyline Symposium, 10 - 12 December 2001, Seattle, Washington, USA, pp. 28-36.

Björheden R., Apel K., Shiba M., Thompson M., 1995. IUFRO Forest work study nomenclature. Swedish University of Agricultural Sciences. Department of Operational Efficiency, Grappenberg: 16.

Borz S.A., Ciobanu V.D., 2013. Efficiency of motor-manual and horse logging in small scale firewood production. African Journal of Agricultural Research 8(24): 3126 - 3135 .

Borz S.A., Dinulică F., Bîrda M., Ignea Gh., Ciobanu D.V., Popa B., 2013. Time consumption and productivity of skidding silver fir (Abies alba Mill.) round wood in reduced accessibility conditions: a case study in windthrow salvage logging from Romanian Carpathians. Annals of Forest Research 56(2): 363-375.

Borz S.A., Ignea Gh., Popa B., Iordache E., 2015. Estimating time consumption and productivity of roundwood skidding in group shelterwood system - a case study in a broadleaved mixed stand located in reduced accessibility conditions. Croatian Journal of Forest Engineering 36(1): 137-146.

Borz S.A., Ignea Gh., Vasilescu M.M., 2014. Small gains in wood recovery rate when disobeying the recommended motor-manual tree felling procedures: another reason to use the proper technical prescriptions. Bioresources 9(4): 6938-6949. DOI: 10.15376/biores.9.4.6938-6949

Corella Justavino F., Jimenez Ramirez R., Menza Perez N., Borz S.A., 2015. The use of OWAS in forest oper- 
ations postural assessment: advantages and limitations. Bulletin of the Transilvania University of Braşov 8(57): 7-16.

Danilović M., Stojnić D., Karić S., Sučević M., 2014. Transport of technical roundwood by forwarder and tractor assembly from poplar plantations. Nova meh. Šumar 35: 11-22.

Dvořák J., Behjou F.K., 2011. Performance standards of medium and high power forwarders. Proceedings of the 44th international symposium on forestry mechanization: Pushing the boundaries with research and innovation in forest engineering, 9-13 October 2011; Graz, Austria.

Gerasimov Y., Senkin V., Väätäinen K., 2012. Productivity of single-grip harvesters in clear-cutting operations in the Northern European part of Russia. European Journal of Forest Research 131(3): 647-657. DOI: 10.1007/ s10342-011-0538-9

Ghaffarian M.R., Stampfer K., Sessions J., 2007. Forwarding productivity in southern Austria. Croatian Journal of Forest Engineering 28(2): 169-175.

Glöde D., Sikström U., 2001. Two felling methods in final cutting of shelterwood, single-grip harvester productivity and damage to the regeneration. Silva Fennica 35(1): 71-83. DOI: 10.14214/sf.604

Heinimann H.R., 2012. Life cycle assesment (LCA) in forestry - state and perspectives. Croatian Journal of Forest Engineering 33(2): 357-372.

Hiesl P., Benjamin J.G., 2013. Applicability of international harvesting equipment productivity studies in Maine, USA. Forests 4: 898-921. DOI: 10.3390/f4040898

Holzleitner F., Stampfer K., Visser R., 2011. Utilization rates and cost factors in timber harvesting based on long-term machine data. Croatian Journal of Forest Engineering 32(2): 501-508.

Inoue K., 1996. Operators' mental strain in operating the high proficient machine. Journal of Forest Research 1(3): 195-197. DOI: 10.1007/BF02348324

Inoue K., Kobayashi H., 1996. Operators' physical strain in operating the high proficient forestry machines. Journal of Forest Research 1(4): 111-115. DOI: 10.1007/ BF02348187

Ionaşcu G., Oprea I., Duţă G., 2006. Harvesting techniques and technologies under the conditions of sustainable forest management. Braşov, Romania: Transilvania University Press, 162 p. [In Romanian].

Laitila J., Väätäinen K., 2013. The cutting productivity of excavator-based harvester in integrated harvesting of pulpwood and energy wood. Baltic Forestry 19(2): 289-300.

Magagnotti N., Spinelli R., 2011. Integrating animal and mechanical operations in protected areas. Croatian Journal of Forest Engineering 32(2): 489-499.
Manner J., Nordfjell T., Lindroos O., 2013. Effects of the number of assortments and log concentration on time consumption for forwarding. Silva Fennica 47(4): 1-19. DOI: $10.14214 /$ sf. 1030

Nurminen T., Korpunen H., Uusitalo J., 2006. Time consumption analysis of the mechanized cut-to-length harvesting system. Silva Fennica 40(2): 335-363. DOI: $10.14214 /$ sf.346

Oprea I., 2008. Timber harvesting technology, Braşov, Romania: Transilvania University Press, 273 p. [In Romanian]

Ovaskainen K., Heikkila M., 2007. Visuospatial cognitive abilities in cut-to-length single-grip timber harvester work. International Journal of Industrial Ergonomics 37(9-10): 771-780. DOI: 10.1016/j.ergon.2007.06.004

Popovici R., 2013. Estimating chainsaw operating costs based on fuel, lubricants and spare parts. Bulletin of the Transilvania University of Braşov 6(55): 63-68.

Rottensteiner C., Tsioras P., Stampfer K., 2012. Wood density impact on hand-arm vibration. Croatian Journal of Forest Engineering 33(2): 303-312.

Spinelli R., Magagnotti N., 2010. Performance and cost of a new mini-forwarder for use in thinning operations. Journal of Forest Research 15(6): 358-364. DOI: 10.1007/s10310-010-0193-x

Spinelli R., Owende P.M.O., Ward S.M., Tornero M., 2004. Comparison of short-wood forwarding systems used in Iberia. Silva Fennica 38(1): 85-94. DOI: $10.14214 /$ sf.437

Stampfer K., Steinmüller T., 2001. A new approach to derive a productivity model for the harvester "Valmet 911 Snake". In: Proceedings of the International Mountain Logging and 11th Pacific Northwest Skyline Symposium, 10-12 December 2001; Seattle, Washington, USA, pp. 28-36.

Stankić I., Porsinšky T., Tomašič Z., Frintič M., 2012. Productivity models for operational planning of timber forwarding in Croatia. Croatian Journal of Forest Engineering 33(1): 61-78.

Tunay M., Melemez K., 2008. Noise induced hearing loss of forest workers in turkey. Pakistan Journal of Biological Science 11(7): 2144-2148. DOI: 10.3923/ pjbs.2008.2144.2148

Visser R., Spinelli R., 2011. Determining the shape of the productivity function for mechanized felling and felling-processing. Journal of Forest Research 17(5): 397402. DOI: $10.1007 / \mathrm{s} 10310-011-0313-2$

Vusić D., Šušnjar M., Marchi E., Spina R., Zečić Z., Picchio R., 2013. Skidding operations in thinning and shelterwood cut of mixed stands - work productivity, energy inputs and emissions. Ecological Engineering 61: 216-223. DOI: 10.1016/j.ecoleng.2013.09.052 